\title{
Rapid Genotyping of Hepatitis C Virus RNA-Isolates Obtained From Patients Residing in Western Europe
}

\author{
G.E.M. Kleter, L.J. van Doorn, L. Stuyver, G. Maertens, J.T. Brouwer, S.W. Schalm, R.A. Heijtink, \\ and W.G.V. Quint \\ Department of Virology, Erasmus University Rotterdam (G.E.M.K., R.A.H.), Department of Internal Medicine II, \\ Dijkzigt Hospital Rotterdam (J.T.B., S.W.S.), Rotterdam; Department of Molecular Biology, Diagnostic Center SSDZ, \\ Delft (L.J.v.D., W.G.V.Q.), the Netherlands; and Innogenetics N.V., Gent, Belgium (L.S., G.M.)
}

Two rapid genotyping methods for hepatitis $C$ virus (HCV), the line probe assay (Inno-LiPA) and the subtype-specific core amplification system [Okamoto et al., (1992b) Journal of General Virology 73:673-679], were applied to $58 \mathrm{HCV}$ isolates which were typed as type $1(n=37)$ and type 2 $(n=21)$ by sequence analysis of the 5 untranslated region ( $\left.5^{\prime} \cup T R\right)$. The line probe assay targets the $5^{\prime}$ UTR and recognized 12 subtype $1 a, 25$ subtype $1 \mathrm{~b}, 18$ subtype $2 \mathrm{a}, 2$ subtype $2 \mathrm{~b}$ and 1 subtype $2 d$ in accordance with sequence analysis of this region. Subtype-specific core amplification revealed 7 discrepancies among the 37 type 1 isolates when compared to LiPA. A different subtype was observed in 3 isolates (1a versus $1 \mathrm{~b}), 2$ isolates remained untyped and 2 isolates showed a coinfection of subtype $1 \mathrm{a}$ and $1 \mathrm{~b}$. The first 5 discrepancies were confirmed by sequence analysis of the core region whereas the coinfection could not be confirmed. Of the 21 type 2 isolates only one could be typed by subtype-specific core amplification. HCV RNA was detected in all 21 cases after the general first round of polymerase chain reaction (PCR). Direct sequencing of the core region indicated sequence variation as a source of failure.

It is concluded that LiPA results are conclusive for typing of HCV. However, LiPA is hampered occasionally for subtyping by lack of subtypespecific sequence variation in $5^{\prime}$ UTR. Subtyping results by subtype-specific core amplification were accurate. However, it seems that this assay is not suitable for the identification of genotype 2 isolates that circulate in patients living in Western Europe. (C) 1995 Wiley-Liss, Inc.

KEY WORDS: line probe assay, subtype-specific amplification, sequence variation, additional HCV subtypes

\section{INTRODUCTION}

Hepatitis $\mathrm{C}$ virus (HCV) is the major etiologic agent of post-transfusion non-A, non-B hepatitis [Choo et al., 1989] and is classified as a distinct genus of the Flaviviridae [Miller and Purcell, 1990]. Several full-length [Choo et al., 1991; Kato et al., 1990; Okamoto et al., 1991, 1992a; Takamizawa et al., 1991] and numerous partial [Bukh et al., 1992, 1993; Chan et al. 1992; Enomoto et al., 1990; Kleter et al., 1994; Mori et al., 1992; Simmonds et al., 1993a; Stuyver et al., 1993b] HCV sequences have been reported and comparison of those sequences revealed considerable heterogeneity between isolates. Recently, a useful classification system, based on phylogenetic analyses, was proposed and has been accepted by the scientific community [Simmonds et al., 1994]. This system discriminates between types and subtypes. Genotypic variation seems to be maintained throughout the entire viral genome, although the level of heterogeneity differs considerably between the various regions of the genome. Nucleotide sequence variation ranges from approximately $10 \%$ in the $5^{\prime}$ UTR [Chan et al., 1992] to nearly $50 \%$ in the E1 [Bukh et al., 1993] and NS5 [Simmonds et al., 1993b] regions. Currently, there is evidence for the existence of at least 9 major types [Tokita et al., 1994b].

Genotyping of HCV isolates is of particular interest for epidemiological studies [Dusheiko et al., 1994; McOmish et al., 1993]. The success of antiviral treatment of chronic HCV infections appears to be related to the viral genotype [Hino et al., 1994; Kobayashi et al., 1993; Tsubota et al., 1994; Yoshioka et al., 1992] and the level of viremia [Hagiwara et al., 1993; Kobayashi et al., 1993; Lau et al., 1993; Yoshioka et al., 1992].

Genotyping can be undertaken by sequence analysis but this is tedious and time-consuming. Recently, several rapid methods for genotyping of HCV have been reported, including subtype-specific polymerase chain

Accepted for publication March 31, 1995.

Address reprint requests to G.E.M. Kleter, Dept. of Virology, Erasmus University Rotterdam, Dr. Mole waterplein 50, 3015 GD Rotterdam, the Netherlands. 
reaction (PCR) in the core region [Okamoto et al., $1992 b, 1993$ ] or in the NS5B region [Chayama et al., 1993], restriction fragment length polymorphism (RFLP) [McOmish et al., 1993; Murphy et al., 1994; Nakao et al., 1991], hybridization of PCR products with type-specific probes [Cha et al., 1992; Enomoto et al., 1990] and reverse hybridization [Stuyver et al., 1993a; van Doorn et al., 1994].

In the present study, two of these rapid methods were applied to 58 type 1 and 2 isolates sequenced in the $5^{\prime}$ UTR region. HCV genotyping was carried out by reverse hybridization with the line probe assay (LiPA), which is aimed at the 5'UTR region, and by the subtype-specific core amplification system [Okamoto et al., $1992 b]$. Discrepant results were analyzed.

\section{MATERIALS AND METHODS Patients}

Plasma samples were obtained by venepuncture and stored at $-70^{\circ} \mathrm{C}$. All 58 patients had elevated alanine aminotransferase (ALT) levels, histological changes compatible with HCV infection, antibodies to hepatitis $C$ virus, no recent history of infection with hepatitis $B$ virus, hepatitis A virus, cytomegalovirus or EpsteinBarr virus, and were between 26 and 74 years old. The patients live in the Netherlands or Belgium.

\section{HCV RNA PCR}

HCV RNA and cDNA were prepared as described previously [Kleter et al., 1993]. For 5' UTR analysis, PCR (40 cycles, $1 \mathrm{~min}$ at $94^{\circ} \mathrm{C}, 2 \mathrm{~min}$ at $48^{\circ} \mathrm{C}, 3 \mathrm{~min}$ at $72^{\circ} \mathrm{C}$ ) was undertaken with antisense primer HCV19 (GTGCACGGTCTACGAGACCT, positions -1 to -20 ) and sense primer HCV18 (GGCGACACTCCACCATAGAT, positions -304 to -324 ) or sense primer HCV35 (TTGGCGGCCGCACTCCACCATGAATCACTCC-CC, positions -296 to -318 ; underlined sequences are not complementary to $\mathrm{HCV}$ ).

\section{Genotyping by LiPA}

Rapid genotyping of HCV isolates by analysis of the 5 'UTR region was carried out with the line probe assay (Inno-LiPA, Innogenetics, Gent, Belgium) [Stuyver et al., 1993a]. Briefly, first round 5'UTR PCR products were subjected to nested PCR with primers HC3 (TCTAGCCATGGCGTTAGTRYGAGTGT; positions -264 to $-238 ; \mathrm{R}=\mathrm{A}$ or $\mathrm{G} ; \mathrm{Y}=\mathrm{T}$ or $\mathrm{C}$ ) and $\mathrm{HC} 4$ (CACTCGCAAGCACCCTATCAGGCAGT; positions -29 to -54) in the presence of bio-11-dUTP. After nested PCR the biotinylated DNA products were denatured by alkaline treatment. Reverse hybridization of the DNA products to general and type-specific $\mathrm{HCV}$ probes which are applied onto a cellulose membrane strip was carried out in the presence of tetramethyl ammonium chloride. After stringent washing, alkaline phosphatase and streptavidin conjungate were added. Finally, the $\mathrm{HCV}$ isolates were identified and classified by scoring the presence or absence of a purple precipitate at the probe lines.

\section{Genotyping by Subtype-Specific Core Amplification}

This rapid typing system was devleoped by Okamoto et al., [1992b] and is based on a universal first round PCR, followed by subtype-specific nested PCR. Four antisense primers in the second PCR yield subtypespecific amplification products of distinct lengths, allowing identification of subtypes $1 \mathrm{a}, 1 \mathrm{~b}, 2 \mathrm{a}$ and $2 \mathrm{~b}$ by agarose gelelectrophoresis. In this study the originally described general sense primers 256 and 104 [Okamoto et al., 1992b] were replaced by, respectively, LD58c (5'-bio-GGTACTGCCTGATAGGGTGCTTGC; positions -57 to -34 ) and LD58s (GCCTGATAGGGTGCTTGC; positions -51 to -34 ). These new general sense primers are located in a completely conserved part of the 5'UTR whereas the original sense primers 256 and 104 were not. The first round of PCR ( 40 cycles, $1 \mathrm{~min}$ at $94^{\circ} \mathrm{C}, 2 \mathrm{~min}$ at $48^{\circ} \mathrm{C}, 3 \mathrm{~min}$ at $72^{\circ} \mathrm{C}$ ) was performed with LD58c and antisense primer 186c (ATITACCCCATGAGITCGGC; positions 410 to 391). One microliter of the first round PCR product was subjected to subtype-specific nested PCR (40 cycles, 1 min at $94^{\circ} \mathrm{C}, 1 \mathrm{~min}$ at $60^{\circ} \mathrm{C}, 1 \mathrm{~min}$ at $72^{\circ} \mathrm{C}$ ) with universal sense primer LD58s and the four antisense primers 132 to 135 as described [Okamoto et al., 1992b], except for primer 133 which was slightly modified by degeneration ( $\mathrm{T}$ and $\mathrm{C}$ ) at position 273 . The antisense primers $132,133,134$ and 135 are specific for HCV subtypes 1a, $1 \mathrm{~b}, 2 \mathrm{a}$ and $2 \mathrm{~b}$, respectively. In additon, antisense primer 296 (GGATAGGCTGACGTCTACCT; positions 196 to 177), which is subtype 1a-specific, was also used for subtype-specific core amplification [Kinoshita et al., 1993] and, together with subtype $1 \mathrm{~b}$-specific primer 235 (CGTGGAAGGCGACAAC; positions 175 to 190 ) used as a ${ }^{32} \mathrm{P}$ radioactive labelled probe by Southern blot analysis. All PCR reactions were undertaken in a Biomed 60 PCR processor (Bittfurth, Germany).

\section{Direct Sequencing of PCR Products}

First round PCR products from the 5 ' UTR were subjected to nested PCR with primers NCR3 (GGGGCGGCCGCCACCATRRATCACTCCCCTGTGAGG, positions -288 to -314$)$ and antisense primer LD58 (5'-bioGGCCGGGGCGGCCGCCAAGCACCCTATCAGGCAG-TACCACAAGGC, positions -37 to -64 ). The first round PCR products from the core region had a biotin moiety at the $5^{\prime}$ end of primer LD58c. Biotinylated PCR products were captured onto streptavidin-coated paramagnetic particles (Dynabeads M-280, Dynal, Oslo, Norway) and processed as described previously [Hultman et al., 1991; Kleter et al., 1994].

\section{Phylogenetic Analysis}

Molecular evolutionary distances between individual isolates were determined by the DNADIST program of the PHYLIP program version 3.5c [Felsenstein, 1993]. 
TABLE I. Country of Birth of Patients Infected With HCV Type 1 and 2

\begin{tabular}{lcc}
\hline & \multicolumn{2}{c}{ HCV genotype } \\
\cline { 2 - 3 } Country of birth & 1 & 2 \\
\hline Belgium & 5 & 3 \\
Germany & 1 & \\
Indonesia & 2 & 3 \\
Italy & 1 & 1 \\
Morocco & 2 & 9 \\
Nigeria & 2 & 5 \\
Surinam & & \\
The Netherlands & 21 & \\
Turkey & 3 &
\end{tabular}

TABLE II. Genotyping of 58 HCV Type 1 and 2 Isolates by LiPA ( $5^{\prime}$ UTR) and Subtype-Specific Core Amplification

\begin{tabular}{|c|c|c|c|c|}
\hline \multicolumn{2}{|c|}{ LiPA } & \multicolumn{3}{|c|}{ Core } \\
\hline Type & $\mathrm{N}$ & Type & $\begin{array}{c}132^{a} \\
N\end{array}$ & $\begin{array}{c}296^{\mathrm{b}} \\
\mathrm{N}\end{array}$ \\
\hline \multirow[t]{4}{*}{$1 \mathrm{a}$} & 12 & $1 a$ & 8 & 7 \\
\hline & & $1 b$ & 1 & 1 \\
\hline & & $1 a+1 b$ & 2 & 2 \\
\hline & & untyped ${ }^{c}$ & 1 & 2 \\
\hline \multirow[t]{2}{*}{$1 b$} & 25 & $1 \mathrm{a}$ & 2 & 2 \\
\hline & & $1 b$ & 23 & 23 \\
\hline $2 a$ & 18 & untyped & 18 & $n d^{d}$ \\
\hline \multirow[t]{3}{*}{$2 \mathrm{~b}$} & 2 & $2 b$ & 1 & nd \\
\hline & & untyped & 1 & nd \\
\hline & 1 & untyped & 1 & nd \\
\hline
\end{tabular}

"Subtype-specific core amplification with antisense primers 132/133/ 134/135.

bubtype-specific core amplification with antisense primers 296/133/ $134 / 135$.

'Untyped: no reaction in the subtype-specific nested PCR

dnd: not determined.

\section{Nucleotide Sequence Accession Number}

The nucleotide sequences have been deposited in the EMBL data library (accession numbers X58937X58953, X78858-X78860 and X78862 for 5'UTR sequences; Z29444-Z29474 and for core sequences).

\section{RESULTS}

HCV isolates were obtained from a large population of patients participating in a study on treatment of chronic hepatitis C, organized by the Benelux Study Group [Brouwer et al., 1993]. All patients lived in the Netherlands or Belgium and were born in different countries (Table I). After sequence analysis of the 5'UTR region, 37 isolates were assigned as type 1 and 21 as type 2 .

\section{5'UTR Genotyping}

HCV genotyping as carried out by sequence analysis of the 5'UTR [Kleter et al., 1994] and LiPA [van Doorn et al., 1994] resulted in identical subtyping for type 1 as well as type 2 isolates (Table II). One type 2 isolate (NE92) has been provisionally classified as " $2 \mathrm{~d}$ " (accession number X78862) because novel covariant mutations were observed at positions -163 and -122 [Kleter et al., 1994]. Sequence analysis of the E1 and NS5B coding regions of this particular isolate confirmed the classification as a separate subtype within HCV genotype 2 [Stuyver et al., 1994].

\section{Subtype-Specific Core Amplification}

The 58 type 1 and 2 isolates were analyzed subsequently also by a modified version of the subtype-specific core amplification method [Okamoto et al., 1992b]. In this study the general sense primers 256 and 104 described originally were replaced by primers LD58c and LD58s, respectively. This modification was introduced to circumvent possible failure of amplification by the general primers due to primer target mismatches (Fig. 1, B207), a phenomenon which was also noticed by Okamoto et al. [1993]. First round PCR products were obtained from all isolates and subsequent subtype-specific amplification was completely dependent on the antisense primers employed in the nested PCR. The core typing results are summarized and compared with LiPA in Table II.

Type 1 isolates. In 2 of the 37 type $1 \mathrm{HCV}$ isolates, coinfections of subtypes $1 \mathrm{a}$ and $1 \mathrm{~b}$ were detected by subtype-specific core amplification, whereas these isolates were typed as subtype 1a by LiPA (Table II). In order to confirm this finding, nested PCR products were analyzed by Southern blot hybridization with subtype 1a- and 1b-specific probes (Fig. 2). Probe 235, which is $1 \mathrm{~b}$-specific, did not hybridize to the $1 \mathrm{~b}$ fragment of 342 bp. Probe 296, which is 1a-specific, hybridized to the $255 \mathrm{pb}$ (1a) as well as the $342 \mathrm{bp}$ (1b) PCR fragment. This result indicated the presence of 1a sequences also in the 342 bp (1b) PCR fragment (Fig. 2, lanes 12 and 13) and therefore, the subtype $1 \mathrm{~b}$ primer 133 had falsely amplified the subtype 1a sequence. Additionally, direct sequencing of the $\mathrm{N}$-terminal core region indicated that these 2 isolates contain only subtype 1a sequences. Direct sequencing of 17 of the 37 type 1 isolates confirmed the subtype-specific core amplification results (Fig. 1).

Two other isolates, NL29 and NL35, remained untyped by subtype-specific core amplification (Table II). Isolate NL35, typed as subtype 1a by $5^{\prime}$ UTR analysis, could not be typed by subtype-specific core amplification (Fig. 2, lane 25). Moreover, Southern blot hybridizations of the first round PCR product with either subtype 1a- or 1b-specific probes (296 and 235, respectively) were also negative (Fig. 2, lane 24). Isolate NL29, typed as subtype 1a by 5 'UTR analysis, was also identified as 1a by subtype-specific core amplification with primer 132 (Fig. 2, lane 23). However, nested PCR with primer 296 (1a) instead of primer 132 did not yield a PCR fragment (Table II). Southern blot hybridizations of first and second round PCR products with subtype 1a- and $1 \mathrm{~b}$-specific probes were also negative (Fig. 2, lanes 22 and 23). The isolates NL29 and NL35 were obtained from patients born in Morocco (Table II). Phylogenetic analysis of 310 nucleotides of the $\mathrm{N}$-terminal core region revealed that these 2 isolates possibly belong to an additional type 1 subtype (Table IIIA). Fur- 


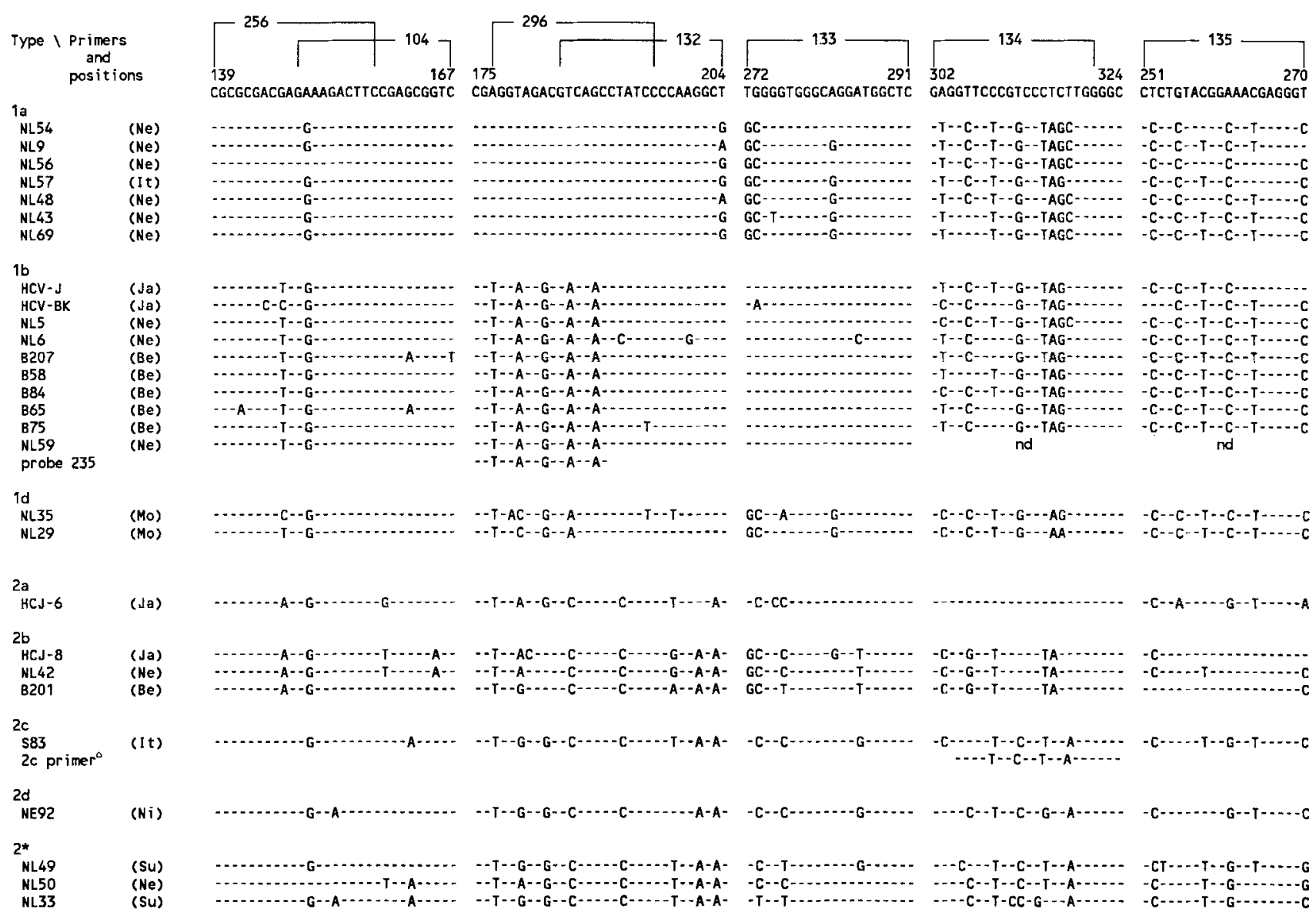

Fig. 1. Comparison of type 1 and type 2 nucleotide sequences in the target region of the 2 universal sense (256 and 104) and the 4 subtypespecific antisense (132 [1a], $133[1 \mathrm{~b}], 134$ [2a] and 135 [2b]) core primers as described by Okamoto et al. [1992b]. Probes 296 and 235 are subtype 1a- and 1b-specific, respectively. Dashes indicate identical nucleotides. The origin of the HCV isolates is given in parentheses:
Be, Belgium; It, Italy; Ja, Japan; Mo, Morocco; Ne, The Netherlands; $\mathrm{Ni}$, Nigeria, and Su, Surinam. HCV.J [Kato et al, 1990]; HCV-BK [Takamizawa et al., 1991]; HC-J6 and HC-J8 [Okamoto et al., 1991, 1992a]; S83 [Bukh et al., 1994]; ○, genotype "2a" primer for European isolates as described by Silini et al. [1993]. ther analysis of the E1 and NS5B regions confirmed classification into subtype 1d (unpublished observation).

In 3 of the 37 type 1 isolates, different subtypes were detected when comparing 5'UTR and Core typing. Two isolates, (NL69 and NL43) were typed as genotype 1b by LiPA but as genotype 1a by subtype-specific core amplification (Fig. 2, lanes 16 and 18). In one isolate (NL59) the opposite was observed (Fig. 2, lane 20). Sequences analysis of the $\mathrm{N}$-terminal core region (nt 1-310) confirmed the results of subtype-specific core amplification (Fig. 1).

Type 2 isolates. All 21 samples of type 2 isolates as deduced from sequence analysis of 5'UTR were HCV RNA positive after the first round of PCR with general primers LD58c and 186c. After the subtype-specific nested PCR, only one isolate was typed as genotype $2 \mathrm{~b}$ (Fig. 2, lane 4) whereas all other type 2 isolates remained untyped (Table II). Five of the 20 untyped samples were sequenced and 3 to 6 mismatches were found to the genotype 2 subtype-specific primers 134 (2a) or
135 (2b; Fig. 1). The obtained sequences showed also mismatches to the HCV genotype "2a" primer for European isolates as described by Silini et al, [1993]. This primer appeared to be specific for $\mathrm{HCV}$ genotype 2c (Fig. 1, S83). The genotype $2 \mathrm{~b}$ isolate that was identified by PCR contained only a single mismatch at the very $5^{\prime}$ end of subtype-specific $2 b$ primer 135 (Fig. 1, B201).

Type 2 core sequences were subjected to phylogenetic analysis and molecular evolutionary distances were determined between the present and published HCV genotype $2 \mathrm{a}(\mathrm{n}=5), 2 \mathrm{~b}(\mathrm{n}=8), 2 \mathrm{c}(\mathrm{S} 83)$ and 2d (NE92) sequences (Table IIIB). From this analysis it appeared that type 2 sequences are highly heterogeneous. The 3 isolates [typed as genotype 2a by LiPA (Fig. 1, NL33, NL49 and NL50)] had greater molecular evolutionary distances to genotype $2 \mathrm{a}$ than the distances observed between type $2 \mathrm{c}$ and $2 \mathrm{~d}$ (Table IIIB). The distances among the 3 isolates were also greater (range 0.06470.0765 ) than the maximum distance between confirmed genotype 2a sequences (Table IIIB, 0.0605). These re- 
TABLE III. Molecular Evolutionary Distances (range and mean \pm S.D.) Between HCV Subtypes and Isolates in the Core Region (nt 1-310)

\begin{tabular}{|c|c|c|c|c|}
\hline \multicolumn{5}{|c|}{ HCV type 1 isolates } \\
\hline $\begin{array}{l}\text { Subtype/ } \\
\text { isolate }\end{array}$ & $1 \mathrm{a}$ & $1 \mathrm{~b}$ & $1 \mathrm{c}$ & NL29 \\
\hline $1 a$ & $\begin{array}{l}0.0065-0.0436 \\
0.0259 \pm 0.0092\end{array}$ & & & \\
\hline $1 b$ & $\begin{array}{l}0.0682-0.1290 \\
0.0895 \pm 0.0128\end{array}$ & $\begin{array}{l}0.0197-0.0641 \\
0.0369 \pm 0.0130\end{array}$ & & \\
\hline $1 \mathrm{c}$ & $\begin{array}{l}0.0572-0.0868 \\
0.0738 \pm 0.0080\end{array}$ & $\begin{array}{l}0.0716-0.1242 \\
0.0941 \pm 0.0112\end{array}$ & $\begin{array}{l}0.0000-0.0230 \\
0.0177 \pm 0.0066\end{array}$ & \\
\hline NL29 & $\begin{array}{l}0.0596-0.0712 \\
0.0633 \pm 0.0037\end{array}$ & $\begin{array}{l}0.0489-0.0859 \\
0.0659 \pm 0.0109\end{array}$ & $\begin{array}{l}0.0593-0.0743 \\
0.0653 \pm 0.0057\end{array}$ & \\
\hline NL35 & $\begin{array}{l}0.0900-0.1097 \\
0.0947 \pm 0.0035\end{array}$ & $\begin{array}{l}0.0757-0.1009 \\
0.0853 \pm 0.0106\end{array}$ & $\begin{array}{l}0.0900-0.1053 \\
0.0990 \pm 0.0057\end{array}$ & 0.0524 \\
\hline \multicolumn{5}{|c|}{ B HCV type 2 isolates } \\
\hline Type & $2 a$ & $2 \mathrm{~b}$ & $2 \mathrm{c}$ & $2 \mathrm{~d}$ \\
\hline $2 a$ & $\begin{array}{l}0.0262-0.0605 \\
0.0384 \pm 0.0096\end{array}$ & & & \\
\hline $2 b$ & $\begin{array}{l}0.0719-0.1236 \\
0.1018 \pm 0.0135\end{array}$ & $\begin{array}{l}0.0065-0.0431 \\
0.0258 \pm 0.0094\end{array}$ & & \\
\hline $2 \mathrm{c}$ & $\begin{array}{l}0.0711-0.0928 \\
0.0805 \pm 0.0100\end{array}$ & $\begin{array}{l}0.0858-0.1079 \\
0.0937 \pm 0.0065\end{array}$ & & \\
\hline $2 \mathrm{~d}$ & $\begin{array}{l}0.0600-0.0817 \\
0.0672 \pm 0.0107\end{array}$ & $\begin{array}{l}0.0860-0.1079 \\
0.0955 \pm 0.0056\end{array}$ & 0.0467 & \\
\hline NL33 & $\begin{array}{l}0.0817-0.1037 \\
0.0891 \pm 0.0093\end{array}$ & $\begin{array}{l}0.1044-0.1271 \\
0.1100 \pm 0.0124\end{array}$ & 0.0572 & 0.0533 \\
\hline NL49 & $0.0683-0.0975$ & $0.0947-0.1093$ & & \\
\hline & $0.0821 \pm 0.0127$ & $0.1020 \pm 0.0056$ & 0.0616 & 0.0649 \\
\hline NL50 & $\begin{array}{l}0.0716-0.1008 \\
0.0861 \pm 0.0112\end{array}$ & $\begin{array}{l}0.0978-0.1166 \\
0.1068 \pm 0.0079\end{array}$ & 0.0717 & 0.0824 \\
\hline
\end{tabular}

sults suggest that these 3 isolates belong to 3 additional HCV genotype 2 subtypes. This observation has been confirmed by sequence analysis of the E1 and NS5B regions (unpublished observations). Interestingly, 2 of the 3 new subtypes were detected in patients born in Surinam. In contrast to this heterogeneity, the core sequence of the two isolates typed as $2 \mathrm{~b}$ by LiPA, were homologous to published $2 \mathrm{~b}$ core sequences (Table IIIB).

\section{DISCUSSION}

The most reliable approach for genotypic classification of HCV isolates would be nucleotide sequencing of the entire RNA genome. Genotypic variation seems to be maintained throughout the viral genome [Chan et al., 1992] and therefore only part of the genome needs to be analyzed. However, for analysis of a large number of samples this is laborious and rapid HCV genotyping assays are therefore required. In this study subtyping of type 1 and type $2 \mathrm{HCV}$ isolates was compared by two rapid assays, i.e., the LiPA and subtype-specific core amplification.

\section{5' UTR Genotyping by LiPA}

For detection of HCV viremia RT-PCR is generally aimed at the 5'UTR region. Therefore, LiPA offers a convenient method for genotyping of $\mathrm{HCV}$ isolates supplementary to $\mathrm{HCV}$ RNA detection in a routine diagnostic setting. The 58 isolates in this study showed that all LiPA results were in accordance with the 5'UTR sequence analysis. However, in $7(19 \%)$ of the 37 genotype 1 isolates, subtyping results by LiPA were not similar to that obtained by subtype-specific core amplification. In the case of $5 \mathrm{HCV}$ isolates this observation may be explained by the minimal sequence difference between subtypes $1 \mathrm{a}$ and $1 \mathrm{~b}$ at position -99 . At this particular position subtype 1a contains an Adenosine whereas subtype $1 \mathrm{~b}$ contains a Guanosine. This minor difference should be considered as lack of sufficient sequence variation in the highly conserved $5^{\prime}$ UTR between subtypes $1 \mathrm{a}$ and $1 \mathrm{~b}$, rather than by recombination between these subtypes. On the other hand, nucleotide variations in the 5'UTR are analyzed thoroughly by LiPA. Each genotype is recognized by 2 or more probes. By assessing hybridization to multiple probes, $26-41 \%$ of the 5'U'TR sequence is determined [Stuyver et al., 1993a]. This contrasted the use of one subtype-specific primer for HCV genotyping in the subtype-specific core amplification system.

\section{Subtype-Specific Core Amplification}

Two problems were encountered with subtype-specific core amplification in this study population of residents in Western Europe. First, although identification of type 1 isolates was clearly possible, $2(5.5 \%)$ of the 37 HCV type 1 isolates were diagnosed as a $1 \mathrm{a}$ and $1 \mathrm{~b}$ coinfection. Theoretically, this phenomenon could be explained by the presence of a small amount of subtype 


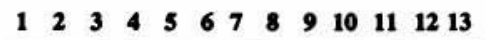

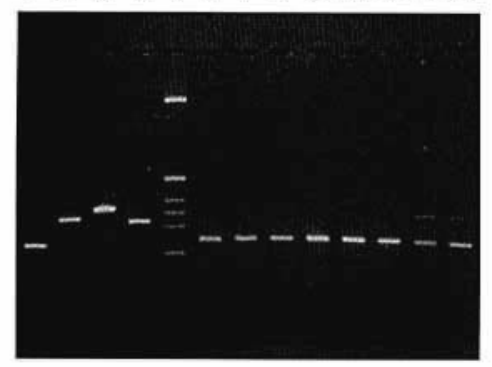

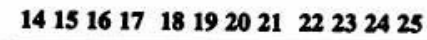

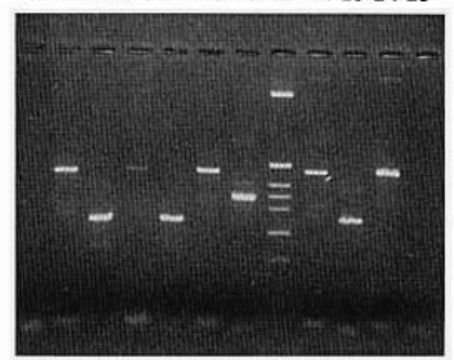

$\begin{array}{lllllllllll}14 & 15 & 16 & 17 & 18 & 19 & 20 & 21 & 22 & 23 & 24\end{array}$
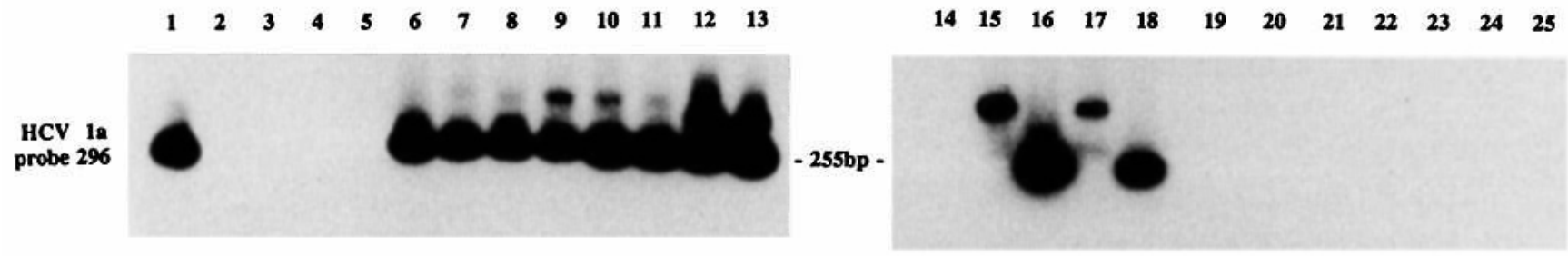

HCV 1b

probe 235

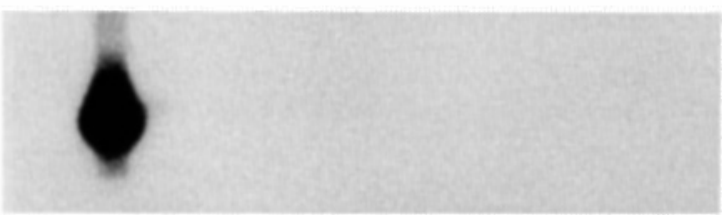

Fig. 2. Identification of subtype-specific nested PCR products obtained with sense primer LD58c and antisense primers 132, 133, 134 and 135. Top: Ethidiumbromide staining of agarose gels. Middle: Southern blot hybridization with subtype 1a-specific probe 296 . Bottom: Southern blot hybridization with subtype 1b-specific probe 235 . Typical results of subtype $1 \mathrm{a}(255 \mathrm{bp}), 1 \mathrm{~b}(342 \mathrm{bp}), 2 \mathrm{a}(372 \mathrm{bp})$ and $2 \mathrm{~b}$ (321 bp) are shown in lanes 1 to 4 , respectively. Lanes 5 and 21

1b sequences that could have been detected by the highly sensitive nested PCR. However, direct-sequencing and Southern blot analyses with subtype 1a- and $1 \mathrm{~b}$-specific probes revealed that these isolates only contained subtype 1a sequences. A more likely explanation therefore, seems to be imperfect annealing of primer 133 to the genotype 1a genome, resulting in aspecific amplification [Andonov and Chaudhary, 1994]. Nonspecific amplification occurred only in HCV genotype 1a isolates (Figs. 1 and 2). The opposite phenomenon, i.e., nonspecific amplification of ' $1 \mathrm{a}$ ' sequences in genotype $1 \mathrm{~b}$ isolates was not observed.

Secondly, identification of type 2 isolates by subtypespecific core amplification was a major problem. Of the $21 \mathrm{HCV}$ genotype 2 isolates, only 1 isolate could be subtyped as genotype $2 \mathrm{~b}$ although a positive result was obtained in all cases after the first round of PCR. The remaining 20 untyped isolates did not yield any nested PCR fragment, even after reducing the annealing temperature in the nested PCR to $55^{\circ} \mathrm{C}$ (data not shown). The antisense core primers are subtype-specific. Therefore, failure of the nested PCR may be explained by mismatches between the subtype-specific primers and their target sequences as is illustrated in Figure 1 (i.e., NL42: 3 mismatches to primer 135).

Recently, identical 5'UTR sequences were described for subtype $2 \mathrm{a}$ and $2 \mathrm{c}$ [Bukh et al., 1993]. Therefore, it is possible that the 18 isolates, typed as $2 \mathrm{a}$ by LiPA, belong to HCV genotype 2c. However, phylogenetic analysis carried out on 3 of these 18 samples suggested that each of these isolates could be classified into yet another subtype. This observation suggests the existence of multiple subtypes among type 2 isolates in Western Europe and requires confirmation by sequence analysis of the E1 and NS5B regions. Theoretically, the subtypespecific " $2 a$ " primer as described by Silini et al. [1993] would not allow typing of the 3 type 2 isolates due to mismatches at essential positions (Fig. 1). These results indicate that HCV type 2 isolates in our study population are considerably different from the published type 2 isolates from Japan [Okamoto et al., 1991,1992b]. Technically, subtype-specific core amplification is a feasible assay for subtyping of HCV isolates. However, improvement of the subtype-specific core amplification assay for typing of $\mathrm{HCV}$ isolates will be difficult due to the extended variation among HCV subtypes. At present more than $29 \mathrm{HCV}$ subtypes have been reported [Bukh et al., 1994; Stuyver et al., 1994; Tokita et al., 1994a,b].

In summary, it appeared that several HCV RNA iso- 
lates remained untyped by subtype-specific core amplification, indicating that this typing method is restricted to the patient population to be analyzed. Furthermore, rapid genotyping results obtained by either LiPA or subtype-specific core amplification were generally in accordance with sequence analysis at, respectively, the 5'UTR and core regions. However, the specificity of both rapid genotyping assays is occasionally hampered due to a lack or excess of sequence variation in their respective target regions as is sequence analysis for HCV typing if restricted to one of these regions.

\section{ACKNOWLEDGMENTS}

The authors thank Dr. A. Elewaut, Dr. M. Hautekeete, Dr. R. Chamuleau, R. Brenard, and the Benelux Study Group on treatment of chronic hepatitis C for providing the patient samples.

\section{REFERENCES}

Andonov A, Chaudhary RK (1994): Genotyping of Canadian hepatitis $\mathrm{C}$ virus isolates by PCR. Journal of Clinical Microbiology 32:20312034 .

Brouwer J', Benelux Multicentre Trial Study Group (1993): Benelux multicentre trial of alpha interferon treatment for chronic hepatitis C: Standard versus high-dose therapy monitored by biochemical and virological markers (interim analysis), Gut, supplement S119-120.

Bukh J, Purcell RH, Miller RH (1992): Sequence analysis of the $5^{\prime}$ noncoding region of hepatitis $\mathrm{C}$ virus. Proceedings of the National Academy of Sciences of the USA 89:4942-4946.

Bukh J, Purcell RH, Miller RH (1993): At least 12 genotypes of hepatitis $\mathrm{C}$ virus predicted by sequence analysis of the putative E1 gene of isolates collected worldwide. Proceedings of the National Academy of Sciences of the USA 90:8234-8238.

Bukh J, Purcell RH, Miller RH (1994): Sequence analysis of the core gene of 14 hepatitis $\mathrm{C}$ virus genotypes. Proceedings of the National Academy of Sciences of the USA 91:8239-8243.

Cha T-A, Beall E, Irvine B, Kolberg J, Chien D, Kio G, Urdea MS (1992): At least five related, but distinct, hepatitis $\mathrm{C}$ viral genotypes exist. Proceedings of the National Academy of Sciences of the USA 89:7144-7148

Chan S-W, McOmish F, Holmes EC, Dow B, Peutherer JF, Follett E, Yap PL, Simmonds P (1992): Analysis of a new hepatitis C virus type and its phylogenetic relationship to existing variants. Journal of General Virology 73:1131-1141.

Chayama K, Tsubota A, Arase Y, Saitoh S, Koida I, Matsumoto T, Kobayashi M, Iwasaki S, Koyama S, Morinaga T, Kumada H (1993): Genotypic subtyping of hepatitis C virus. Journal of Gastroenterology and Hepatology 8:150-156.

Choo Q-L, Kuo G, Weiner AJ, Overby LR, Bradley DW, Houghton M (1989): Isolation of a cDNA clone derived from a blood-borne non-A, non-B viral hepatitis genome. Science 244:359-362.

Choo Q-L, Richman KH, Han JH, Berger K, Lee C, Dong C, Gallegos C, Coit D, Medina-Selby A, Barr PJ, Weiner AJ, Bradley DW, Kuo G, Houghton M (1991): Genetic Organizaiton of the hepatitis C virus. Proceedings of the National Academy of Sciences of the USA 88:2451-2455.

Dusheiko G, Schmilovitz-Weiss H, Brown D, McOmish F, Yap P-L, Sherlock S, McIntyre N, Simmonds P (1994): Hepatitis C virus genotypes: An investigation of type-specific differences in geographic origin and disease. Hepatology 19:13-18.

Enomoto N, Takada A, Nakao T, Date T (1990): There are two major types of hepatitis C virus in Japan. Biochemical and Biophysical Research Communications 170:1021-1025.

Felsenstein J (1993): PHYLIP (Phylogenetic inference Package) version 3.5c. Distributed by the author. Department of Genetics, University of Washington, Seattle, WA, USA.

Hagiwara H, Hayashi N, Mita E, Takehara T, Kasahara A, Fusamoto H, Kamada T (1993): Quantitative analysis of hepatitis $C$ virus RNA in serum during interferon alfa therapy. Gastroenterology $104: 877-883$
Hino K, Sainokami S, Shimoda K, Iino S, Wang Y, Okamoto H, Miyakawa Y, Mayumi M (1994): Genotypes and titers of hepatitis C virus for predicting the response to interferon in patients with chronic hepatitis C. Journal of Medical Virology 42:299-305.

Hultman T, Bergh S, Moks T, Uhlén M (1991): Bidirectional solidphase sequencing of in vitro-amplified plasmid DNA. Bio'Techniques 10:84-93.

Kato N, Hijikata M, Ootsuyama Y, Nakagawa M, Ohkoshi S, Sugimura T, Shimothono $\mathrm{K}$ (1990): Molecular cloning of the human hepatitis $C$ virus genome from Japanese patients with non-A non-B hepatitis. Proceedings of the National Academy of Sciences of the USA 87:9524-9528.

Kinoshita T, Miyake K, Okamoto H, Mishiro S (1993): Imported hepatitis $\mathrm{C}$ virus genotypes in Japanese haemophiliacs. Journal of Infectious Diseases 168:249-250.

Kleter GEM, Brouwer JT, Heijtink RA, Schalm SW, Quint WGV (1993): Detection of hepatitis C virus RNA in patients with chronic hepatitis $C$ virus infections during and after therapy with alphainterferon. Antimicrobial Agents and Chemotherapy 37:595-597.

Kleter GEM, van Doorn L-J, Brouwer JT, Schalm SW, Heijtink RA, Quint WGV (1994): Sequence analysis of the 5'-untranslated region in isolates of at least four genotypes of hepatitis $\mathrm{C}$ virus in The Netherlands. Journal of Clinical Microbiology 32:306-310.

Kobayashi Y, Watanabe S, Konishi M, Yokoi M, Kakehashi R, Kaito M, Kondo M, Hayashi Y, Jomori T, Suzuki S (1993): Quantitation and typing of serum hepatis $\mathrm{C}$ virus RNA in patients with chronic hepatitis C treated with interferon- $\beta$. Hepatology 18:1319-1325.

Lau JYN, Davis GL, Kniffen J, Qian K-P, Urdea MS, Chan CS, Mizokami M, Neuwald PD, Wilber JC (1993): Significance of serum hepatitis C virus RNA levels in chronic hepatitis C. Lancet 341 : 1501-1504,

McOmish F, Chan S-W, Dow BC, Gillon J, Frame WD, Crawford RJ, Yap PL, Follett EAC, Simmonds P (1993): Detection of three types of hepatitis $\mathrm{C}$ virus in blood donors: investigation of type-specific differences in serologic reactivity and rate of alanine aminotransferase abnormalities. Transfusion 33:7-13.

Miller RH, Purcell RH (1990): Hepatitis C virus shares amino acid sequence similarity with Pestiviruses and Flaviviruses as well as members of two plant virus supergroups. Proceedings of the $\mathrm{Na}$ tional Academy of Sciences of the USA 87:2057-2061.

Mori S, Kato N, Yagyo A, Tanaka T, Ikeda Y, Petchclai B, Chiewsilp P, Kurimura T, Shimotohno K (1992): A new type of hepatitis C virus in patients in Thailand. Biochemical and Biophysical Research Communications 183:334-342.

Murphy D, Willems B, Delage G (1994): Use of 5 ' noncoding region for genotyping hepatitis C virus. Journal of Infectious Diseases 169: $473-475$.

Nakao T, Enomoto N, Takada N, Takada A, Date T (1991): Typing of hepatitis $\mathrm{C}$ virus genomes by restriction fragment length polymorphism. Journal of General Virology 72:2105-2112.

Okamoto H, Okada S, Sugiyami Y, Kurai K, Lizuka H, Machida A Miyakawa Y, Mayumi M (1991): Nucleotide sequence of the genomic RNA of hepatitis $C$ virus isolated from a human carrier Comparison with reported isolates for conserved and divergent regions. Journal of General Virology 72:2697-2704.

Okamoto H, Kurai K, Okada S-I, Yamamoto K, Lizuka H, Tanaka T, Fukuda S, Tsuda F, Mishiro S (1992a): Full-length sequence of a hepatitis $\mathrm{C}$ virus genome having poor homology to reported isolates: Comparative study of four distinct genotypes. Virology 188 : $331-341$.

Okamoto H, Sugiyama Y, Okada S, Kurai K, Akahane Y, Sugai Y, Tanaka T, Sato K, Tsuda F, Miyakawa Y, Mayumi M (1992b): Typing hepatitis $\mathrm{C}$ virus by polymerase chain reaction with typespecific primers: Application to clinical surveys and tracing infectious sources. Journal of General Virology 73:673-679.

Okamoto H, Tokita H, Sakamoto M, Horikita M, Kojima M, Iizuka H, Mishiro S (1993): Characterization of the genomic sequence of type $\mathrm{V}$ (or $3 \mathrm{a}$ ) hepatitis $\mathrm{C}$ virus isolates and $\mathrm{PCR}$ primers for specific detection. Journal of General Virology 74:2385-2390.

Silini E, Bono F, Cerino A, Piazza V, Solicia E, Mondelli MU (1993): Virological features of hepatitis $C$ virus infection in hemodialysis patients. Journal of Clinical Microbiology 31:2913-2917.

Simmonds P, McOmish F, Yap PL, Chan S-W, Lin CK, Dusheiko G, Saeed AA, Holmes EC (1993a): Sequence variability in the $5^{\prime}$ noncoding region of hepatitis $C$ virus: identification of a new virus type and restrictions on sequence diversity. Journal of General Virology 74:661-668. 
Simmonds P, Holmes EC, Cha T-C, Chan S-W, McOmish F, Irvine B, Beall E, Yap PL, Kolberg J, Urdea MS (1993b): Classification of hepatitis $\mathrm{C}$ virus into six major genotypes and a series of subtypes by phylogenetic analysis of the NS-5 region. Journal of General Virology 74:2391-2399.

Simmonds P, Alberti A, Alter HJ, et al. (1994): A proposed system for nomenclature of hepatitis $C$ viral genotypes. Hepatology 19:13211324.

Stuyver L, Rossau R, Wyseur A, Duhamel M, Vanderborght B, Van Heuverswyn $H$, Maertens $G$ (1993a): Typing of hepatitis $C$ virus isolates and characterization of new subtypes using a line probe assay. Journal of General Virology 74:1093-1102.

Stuyver L, Van Arnhem W, Wyseur A, DeLeys R, Maertens G (1993b): Analysis of the putative E1 envelope and NS4a epitope regions of HCV type 3. Biochemical and Biophysical Research Communications 192:635-641.

Stuyver L, Van Arnhem W, Wyseur A, Hernandez F, Delaporte E, Maertens $G$ (1994): Classification of hepatitis $C$ viruses based on polygenetic analysis of the E1 and NS5b regions and identification of 5 new subtypes. Proceedings of the National Academy of Sciences of the USA 91:10134-10138.

Takamizawa A, Mori C, Fuke I, Manabe S, Murakami S, Fujita J, Onishi E Andoh T, Yoshida I, Okayama H (1991): Structure and organization of the hepatitis $\mathrm{C}$ virus genome isolated from human carriers. Journal of Virology 65:1105-1113.
Tokita H, Man Shrestha SM, Okamoto H, Sakamoto M, Horikita M, Iizuka H, Shrestha S, Miyakawa Y, Mayumi M (1994a): Hepatitis $\mathrm{C}$ virus variants from Nepal with novel genotypes and their classification into the third major group. Journal of General Virology 75:931-936.

Tokita $H$, Okamoto H, Tsuda F, Song P, Nakata S, Chosa T, lizuka H, Mishiro S, Miyakawa Y, Mayumi M (1994b): Hepatitis C virus variants from Vietnam are classifiable into the seventh, eighth and ninth major genetic groups. Proceedings of the National Academy of Sciences of the USA 91:11022-11026.

Tsubota A, Chayama K, Ikeda K, Yasuji A, Koida I, Saitoh S, Hashimoto M. Iwasaki S, Kobayashi M, Hiromitsu K (1994): Factors predictive of response to interferon- $\alpha$ therapy in hepatitis $C$ infection. Hepatology 19:1088-1094.

van Doorn L-J, Kleter B, Stuyver L, Maertens G, Brouwer H, Schalm S, Heijtink R, Quint W (1994): Analysis of hepatitis C virus genotypes by a Line Probe Assay (LiPA) and the correlation with antibody profiles. Journal of Hepatology 21:122-129.

Yohsioka K, Kakumu K, Wakita T, Ishikawa T, Itoh Y, Takayanagi M, Higashi T, Shibata M, Morishima T (1992): Detection of hepatitis $\mathrm{C}$ virus by polymerase chain reaction and response to interferon- $\alpha$ therapy: Relationship to genotypes of hepatitis $c$ virus. Hepatology 16:293-299. 